\title{
TINJAUAN KEPUASAN PETUGAS REKAM MEDIS TERHADAP RUANG REKAM MEDIS DI RUMAH SAKIT GRIYA HUSADA MADIUN
}

\author{
RISKA WATI ISKANDAR PUTRI \\ Program Studi D-III Rekam Medis dan Informasi Kesehatan Sekolah Tinggi Ilmu Kesehatan \\ Buana Husada Ponorogo \\ Email : riskaiskandar38@gmail.com
}

\begin{abstract}
One of the good medical record units, the existence of supporting facilities and infrastructure makes the medical record officers more productive. The Medical Record Officer needs a room that is suitable for comfortable conditions. Looking from the ergonomic side, the medical record room must have an entilation so that air and light can enter the room is not damp and stuffy, the storage space must be in accordance with the polyclinic, besides lighting, temperature, humidity, and the effects and air circulation also need an attention. This researh relates to the satisfaction of medical record officers to the medical record room at Griya Husada Madiun Hospital.The reseach used descriptive method by Cross Sectional design and data collection method used are interview, questionnaire and documentation. The population and sample in this study were all medical record officers totaling 3 people and the sample used total sampling.Based on the results of the study, the medical record officers were not satisfied with the current medical record room. The condition of the medical record room at Griya Husada Madiun Hospital had very minimal movement space and became one with the emergency patient's medical record filling documents and extensive of the room is too narrow so that it feels tight full of things that will hinder the work and productivity of the officers, besides the maximum lighting and medical record space.
\end{abstract}

\section{Keywords: Satisfaction of medical record officers}

\section{PENDAHULUAN}

Pelayanan kesehatan di Indonesia sangat beragam macamnya, salah satu diantaranya adalah rumah sakit. Menurut undang-undang No. 44 tahun 2009 tentang rumah sakit, sebagaimana yang dimaksud rumah sakit adalah institusi pelayanan kesehatan yang menyelenggarakan pelayanan kesehatan perseorangan secara paripurna yang menyediakan pelayanan rawat inap, rawat jalan, gawat darurat. Menurut undangundang kesehatan No. 44 tahun 2009 terkait rumah sakit dalam pengaturan penyelenggaraan rumah sakit, rumah sakit bertujuan untuk meningkatkan mutu pelayanan kesehatan didukung oleh berbagai unit atau bagian yang ada dirumah sakit itu sendiri. Adapun salah satu pendukung rumah sakit adalah unit rekam medis.

Menurut Permenkes No. 269/MENKES/PER/III/2008, Rekam Medis adalah berkas yang berisikan catatan dan dokumen tentang identitas pasien, pemeriksaan, pengobatan, tindakan dan pelayanan lain yang telah diberikan kepada pasien. Rekam medis merupakan bagian penting dari rumah sakit yang memberikan informasi tertulis terkait keadaan pasien. Rumah Sakit harus membuat rekam medis baik itu yang rawat jalan, rawat darurat maupun rawat inap jika ada demi 


\section{Jurnal Delima Harapan 2020}

tindak lanjut pasien ketika berkunjung lagi ke rumah sakit.

Unit rekam medis adalah salah satu unit yang berada di rumah sakit yang kegiatan utamanya adalah sebagai penyelenggara dan pengelolaan rekam medis yang meliputi tempat pendaftaran pasien, assembling, filling, coding \& indexing serta analising \& reporting.

Salah satu unit rekam medis yang baik adanya sarana dan prasarana yang mendukung sebagai fasilitas yang membuat petugas rekam medis semakin produktif. Petugas Rekam Medis seharusnya bekerja diruang yang memadai dengan kondisi yang nyaman. Ditinjau dari sisi ergonomi ruang rekam medis harus mempunyai jendela luar agar udara dan cahaya matahari dapat masuk sehingga ruangan tidak lembab dan pengap, ruangan penyimpanan sebaiknya berdekatan dengan poliklinik, selain itu pencahayaan, suhu, kelembapan, kebisingan dan sirkulasi udara juga perlu diperhatikan. Hal dibuktikan dengan pengertian ergonomi yaitu penerapan ilmu-ilmu geologis tentang manusia ilmu-ilmu teknik dan teknologi untuk mencapai penyesuaian satu sama lain secara optimal dari manusia terhadap pekerjaannya yang manfaat daripadanya diukur dengan efisiensi dan kesejahteraan kerja (Nurminanto,2004). Penyelenggaraan rekam medis yang bermutu harus ditunjang dengan sarana yang memadai. Kondisi ruangan yang kurang memadai akan mengganggu kinerja ataupun produktivitas yang membuatnya tidak nyaman. Kondisi ruang rekam medis yang kurang luas, cahaya yang kurang dan ruangan yang sempit juga mempengaruhi pelayanan petugas dan produktivitas serta kinerja dari petugas itu sendiri. Hal ini mempengaruhi kenyamanan petugas dalam menyelenggarakan berkas rekam medis. Hal ini dibuktikan dengan pengertian Mutu merupakan keseluruhan karekteristik barang atau jasa yang menunjukkan kemampuannya dalam memuaskan kebutuhan konsumen, baik serupa kebutuhan yang dinyatakan ataupun kebutuhan yang tersirat (Pohan, 2007)

Fasilitas kerja dan lingkungannya saling berinteraksi dengan tujuan utama yaitu menyesuaikan suasana kerja dengan manusianya (Nurmianto, 2008). Kenyamanan lingkungan kerja sangat membantu dalam meningkatkan produktivitas kerja para petugas dalam memberikan pelayanan di Rumah Sakit, sehingga pasien mendapatkan pelayanan maksimal. Kondisi ruangan yang panas akan mengakibatkan petugas mengantuk dan letih dalam bekerja dan akan mengurangi kestabilan kerja yang akan berdampak pada kesalahan kerja. Sebaliknya, kondisi dingin akan mengakibatkan rasa malas untuk bekerja yang akan mengurangi kosentrasi (Nurmianto, 2008).

Studi pedahuluan yang dilakukan peneliti pada tanggal 18 Desember 2018 dengan melakukan wawancara kepada 3 petugas rekam medis di Rumah Sakit Griya Husada Madiun, diperoleh hasil bahwa masalah yang dihadapi di unit rekam medis antara lain petugas merasa kurang nyaman terhadap ruang unit rekam medis yang sempit dikarenakan bagian assembling, coding \& indexing serta filling gawat darurat masih menjadi satu di tempat ruang rekam medis. Hal itu dibuktikan dengan luas ruang rekam medis yang berukuran sekitar $6 \mathrm{~m} \times 2 \mathrm{~m}$, tidak adanya sirkulasi udara dan jauhnya ruang rekm medis dengan poliklinik selain itu pencahayaan yang kurang serta ruang rekam medis yang berada di sebelah ruang jaga IGD menyebabkan petugas tidak fokus dan kurang konsentrasi disebabkan adanya orang lain yang keluar masuk didepan pintu ruang rekam medis. 
Menurut petugas rekam medis, kendala tersebut sudah pernah disampaikan ke direktur Rumah Sakit tetapi kendala tersebut belum ada tindakan secara nyata karena keterbatasan ruang yang ada di rumah sakit tersebut, dampaknya petugas merasa kurang nyaman dalam melaksanakan pekerjaan dan produktivitas petugas juga kurang maksimal.

Berdasarkan permasalahan yang ada di unit rekam medis Rumah Sakit Griya Husada Madiun, seharusnya diadakan evaluasi terkait ruangan rekam medis dan mengusulkan ruang rekam medis.

\section{TUJUAN PENELITIAN}

Tujuan umum dari penelitian ini adalah untuk mengetahui kepuasan petugas rekam medis terhadap ruang rekam medis di Rumah Sakit Griya Husada Madiun. Tujuan khusus dari penelitian ini adalah untuk Mengetahui kepuasan petugas rekam medis terhadap ruang rekam medis di Rumah Sakit Griya Husada Madiun, Mengetahui kondisi ruang rekam medis di Rumah Sakit Griya Husada Madiun, Mengetahui pencahayaan dan luas ruang rekam medis di Rumah Sakit Griya Husada Madiun.

\section{METODE PENELITIAN}

Jenis penelitian ini menggunakan deskriptif. Lokasi penelitian adalah di rumah sakit griya husada madiun. Sampel penelitian adalah 3 orang petugas rekam medis. Hasil pengolahan data penelitan ini dianalisa secara deskriptif.

\section{HASIL PENELITIAN}

\section{Data Umun}

a. Karakteristik responden berdasarkan umur di Rumah Sakit Griya Husada Madiun.
Tabel 1. Karakteristik responden berdasarkan umur di Rumah Sakit Griya Husada Madiun 2019

\begin{tabular}{clcc}
\hline No & Umur & Frekuensi & Presentase \\
\hline $\mathbf{1}$ & $26-30$ & 2 & $67 \%$ \\
$\mathbf{2}$ & $31-35$ & 1 & $33 \%$ \\
\hline & Jumlah & $\mathbf{3}$ & $\mathbf{1 0 0 \%}$ \\
\hline
\end{tabular}

Berdasarkan tabel 1. di atas terlihat bahwa sebagian besar responden berusia 26-30 tahun berjumlah 2 orang dengan presentase sebesar $67 \%$, dan responden yang berusia 31-35 tahun sebanyak 1 orang dengan presentase $33 \%$.

b. Karakteristik responden berdasarkan jenis kelamin di

Rumah Sakit Griya Husada Madiun Tabel 2. Karakteristik responden berdasarkan jenis kelamin di Rumah Sakit Griya Husada Madiun 2019.

\begin{tabular}{llcl}
\hline No. & Jenis & Frekuensi & \% \\
& Kelamin & & \\
\hline 1 & Laki-laki & 1 & $33 \%$ \\
2 & Perempuan & 2 & $67 \%$ \\
\hline & Jumlah & $\mathbf{3}$ & $\mathbf{1 0 0 \%}$ \\
\hline
\end{tabular}

Berdasarkan tabel 2. di atas terlihat bahwa sebagian besar responden berjenis kelamin perempuan dengan rincian laki-laki sebanyak 1 orang responden dengan presentase $33 \%$ dan jumlah responden perempuan sebanyak 2 orang dengan presentase $67 \%$.

c. Karakteristik responden berdasarkan pendidikan di Rumah Sakit Griya Husada Madiun.

Tabel 3. Karakteristik responden berdasarkan pendidikan di Rumah Sakit Griya Husada Madiun 2019.

\begin{tabular}{llcc}
\hline No & Pendidikan & Frekuensi & \% \\
\hline $\mathbf{1}$ & D3 RMIK & 2 & $67 \%$ \\
$\mathbf{2}$ & S1 & 1 & $33 \%$ \\
& Akutansi & & \\
\hline & Jumlah & $\mathbf{3}$ & $\mathbf{1 0 0 \%}$ \\
\hline
\end{tabular}


Berdasarkan tabel 3. di atas terlihat bahwa sebagian besar responden yang berpendidikan D3 RMIK berjumlah 2 orang dengan presentase sebesar 67\%, dan responden yang berpendidikan S1 Akutansi sebanyak 1 orang dengan presentase $33 \%$.

\section{Data khusus}

a. Kepuasan petugas rekam medis terhadap ruang rekam medis di Rumah Sakit Griya Husada Madiun.

Berdasarkan wawancara yang dilakukan peneliti pada tanggal 15 Mei 2019, 17 Mei 2019 dan 10 juni 2019 kepada petugas rekam medis di Rumah Sakit Griya Husada Madiun mengatakan bahwa petugas kurang puas terhadap ruang rekam medis, hal itu mempengaruhi produktifitas petugas dalam melakukan pekerjaan.

Ketidakpuasan tersebut dikarenakan kurangnya fasilitas yang memadai di ruang rekam medis saat ini. Ruang rekam medis yang sempit dan kurang luas sangat membuat petugas kurang nyaman dalam melakukan aktifitas pekerjaan. Ruang penyimpanan dokumen rekam medis gawat darurat yang masih menjadi satu dengan uang rekam medis juga menjadikan ruang semakin sesak penuh.

b. Kondisi ruang rekam medis di Rumah Sakit Griya Husada Madiun.

Berdasarkan wawancara yang dilakukan oleh peneliti pada tanggal 15 Mei 2019, 17 Mei 2019 dan 10 juni 2019 terkait kondisi ruang rekam medis di Rumah Sakit Griya Husada Madiun, Petugas mengatakan bahwa kondisi ruang rekam medis belum tertata rapi dikarenakan jarak antara meja kerja terlalu berhimpitan karena kendala ruang yang sempit.

Ruang rekam medis itu sendiri juga menjadi satu dengan ruang penyimpanan dokumen rekam medis pasien gawat darurat, sehingga ruangan tersebut menjadi penuh sesak, selain itu petugas mengatakan ruang rekam medis yang ada saat ini belum tertata secara rapi, pencahayaan kurang terang karena tidak ada cahaya matahari yang masuk ke dalam ruangan, selain itu petugas juga mengatakan bahwa seharusnya ruangan kurang luas sehingga terasa sesak penuh. Petugas juga mengeluhkan susah untuk mencari dokumen rekam medis pasien karena belum tertata rapi

c. Pencahayaan dan luas ruang rekam medis di Rumah Sakit Griya Husada Madiun.

Berdasarkan wawancara yang dilakukan peneliti pada tanggal 15 Mei 2019, 17 Mei 2019 dan 10 juni 2019 terkait kondisi ruang rekam medis di Rumah Sakit Griya Husada Madiun. Petugas mengatakan bahwa kondisi ruang rekam medis dengan luas ruangan $3 \mathrm{~m} \mathrm{x}$ $12 \mathrm{~m}$ untuk pencahayaan ruangan 142,2 lux, selain itu petugas mengatakan ruang rekam medis yang ada saat ini belum tertata secara rapi, pencahayaan kurang terang karena tidak ada cahaya matahari yang masuk ke dalam ruangan, selain itu petugas juga mengatakan bahwa seharusnya ruangan kurang luas sehingga terasa sesak penuh hal itu akan menghambat pekerjaan dan produktivitas petugas. 


\section{PEMBAHASAN}

Pembahasan dari hasil penelitian Tinjauan Kepuasan Petugas Rekam Medis Terhadap Ruang Rekam Medis di Rumah Sakit Griya Husada Madiun.

a. Kepuasan Petugas Rekam Medis terhadap ruang rekam medis di Rumah Sakit Griya Husada Madiun.

Berdasarkan wawancara yang dilakukan peneliti pada kepada petugas rekam medis di Rumah Sakit Griya Husada Madiun petugas kurang puas terhadap ruang rekam medis, hal itu mempengaruhi produktifitas petugas dalam melakukan pekerjaan. Ketidakpuasan tersebut dikarenakan kurangnya fasilitas yang memadai di ruang rekam medis saat ini. Ruang rekam medis yang sempit dan kurang luas sangat membuat petugas kurang nyaman dalam melakukan aktifitas pekerjaan.

Ruang penyimpanan dokumen rekam medis gawat darurat yang masih menjadi satu dengan ruang rekam medis juga menjadikan ruang semakin sesak penuh, selain itu ruang rekam medis juga belum tertata rapi sehingga memiliki ruang gerak yang kurang oleh karena itu dapat menghambat pekerjaan petugas rekam medis.

Kepuasan adalah perasaan senang atau kecewa seesorang yang muncul setelah membandingkan kinerja atau hasil yang diharapkan, maka jika kinerja berada dibawah harapan petugas tidak puas, jika kinerja melebihi harapan, pelanggan amat puas atau senang (Kotler 2006 dalam Hamid 2010).

Aspek kepuasan kerja salah satunya adalah Kondisi Kerja yang Mendukung. Karyawan peduli akan lingkungan kerja baik untuk kenyamanan pribadi maupun untuk memudahkan mengerjakan tugas. Studi-studi memperagakan bahwa karyawan lebih menyukai keadaan sekitar fisik yang tidak berbahaya atau merepotkan. Temperatur (suhu), cahaya, kebisingan, dan faktor lingkungan lain seharusnya tidak esktrem (Herlambang, 2018).

Berdasarkan hal di atas diidentifikasi perlu adanya perbaikan pada bagian ruang rekam medis, agar pelaksanaan pengelolaan rekam medis dapat berjalan dengan lancar dan kinerja petugas menjadi maksimal.

b. Kondisi ruang rekam medis di Rumah Sakit Griya Husada Madiun.

Berdasarkan wawancara yang telah dilakukan oleh peneliti bahwa kondisi ruang rekam medis kurang baik, dibuktikan dengan ruang rekam medis yang masih menjadi satu dengan tempat penyimpanan dokumen pasien gawat darurat, selain itu tata meja antara satu dengan yang lainnya terlalu berdekatan. Meja yang terlalu berdekatan mebuat petugas kesulitan jika ingin melakukan aktivitas pengambilan dokumen atau yang lainnya. Kondisi ruang rekam medis di Rumah Sakit Griya Husada Madiun saat ini belum tertata dengan rapi karena ruang rekam medis belum pasti, sehingga jarak antara meja satu dengan meja lainnya belum teratur. Ruang rekam medis itu juga menjadi satu dengan filling gawat darurat sehingga petugas susah untuk mencari dokumen pasien lama. Ruang rekam medis saat ini masih belum bisa dikatakan rahasia karena banyak petugas lain yang masuk ke ruang tersebut.

Tata ruang kerja (layout) adalah penentuan mengenai kebutuhankebutuhan ruang serta penggunaan ruangan secara terperinci dengan susunan yang praktis dan biaya 
yang layak yang dianggap mampu memberikan kepuasan kepada petugas terhadap pekerjaan yang dilakukan dan memberikan kesan yang mendalam bagi petugas.

Menurut Depkes RI (2006) tentang persyaratan ruang penyimpanan berkas rekam medis antara lain adalah ruangan letaknya harus strategis sehingga mudah dan cepat dalam pengambilan, penyimpanan dan distribusi, Harus ada pemisah ruangan rekam medis aktif dan in aktif, hanya petugas penyimpanan yang boleh berada di ruang penyimpanan.

Ruangan rekam medis harus dapat memberi pelayanan yang cepat kepada seluruh pasien, mudah dicapai dari segala penjuru dan mudah menunjang pelayanan administrasi. Alat penyimpanan yang baik, penerangan yang baik, pengaturan suhu ruangan, pemeliharaan ruangan, perhatian terhadap faktor keselamatan petugas, bagi suatu ruangan penyimpanan rekam medis sangat membatu memelihara dan mendorong kegairahan kerja dan produktivitas pegawai. Penerangan atau lampu yang baik, menghindari kelelahan penglihatan petugas, selain itu perlu diperhatikan pengaturan suhu ruangan, kelembaban, pencegahan debu dan pencegahan bahaya kebakaran.

Dari penjelasan diatas maka seharusnya perlu adanya evaluasi terkait ruang rekam medis agar kedepannya dapat lebih baik lagi, selain itu evaluasi tata ruang rekam medis juga perlu dipertimbangkan kembali agar tercipta suasana kerja yang nyaman dan hal itu pastinya akan memacu produktivitas petugas dalam melakukan pekerjaan. c. Pencahayaan dan luas ruang rekam medis di Rumah Sakit Griya Husada Madiun.

Pencahayaan dan luas ruang rekam medis di Rumah Sakit Griya Husada Madiun saat ini dengan 142, 2 lux hal itu dibuktikan dengan pengukuran menggunakan lux meter yang disediakan oleh pihak rumah sakit. Luas ruangan $2 \mathrm{mx} 6 \mathrm{~m}$ yang mana dalam ruangan tersebut terdapat 3 meja dan 3 kursi untuk petugas, ada 2 buah rak yang terbuat dari kayu masing-masing berukuran $165 \mathrm{~cm} \times 175 \mathrm{~cm}$. Rak yang terbuat dari besi juga terdapat 2 rak besi yang berukuran $240 \mathrm{~cm} \mathrm{x}$ $200 \mathrm{~cm}$. Ruang rekam medis di rumah sakit Griya Husada di dalamnya juga terdapat 3 meja yang masing-masing berukuran $120 \mathrm{~cm} \mathrm{x}$ $58 \mathrm{~cm} \times 7 \mathrm{~cm}$ serta tumpukan dokumen rekam medis rawat inap yang datanya akan diolah, selain itu juga terdapat beberapa tumpukan dokumen rekam medis gawat darurat yang belum tertata sebagaimana mestinya. Hal tersebut dapat menghambat pekerjaan petugas dikarenakan sulit mencari dokumen rekam medis.

Suatu kondisi lingkungan dikatakan baik atau sesuai apabila manusia dapat melaksanakan kegiatannya secara optimal, sehat, aman, nyaman.Ketidaksesuaian lingkungan kerja dapat dilihat akibatnya dalam jangka waktu yang lama. Keadaan lingkungan yang kurang baik dapat menuntut tenaga dan waktu yang lebih banyak dan tidak mendukung diperolehnya waktu yang lebih banyak dan tidak mendukung diperolehnya rencangan sistem kerja yang efisien.

Beberapa faktor yang dapat mempengaruhi terbentuknya suatu kondisi lingkungan kerja dikaitkan dengan kemampuan manusia atau pegawai menurut Sedarmayanti 
(2013) diantaranya adalah yang pertama penerangan atau pencahayaan di tempat kerja, penerangan atau pencahayaan sangat berpengaruh dengan keselamatan dan kelancaran kerja, oleh sebab itu perlu diperhatikan adanya penerangan atau cahaya yang baik. Cahaya yang kurang baik dapat mengakibatkkan penglihatan menjadi kurang jelas, sehingga pekerjaan akan lambat dan banyak mengalami kesalahan dan pada akhirnya menyebabkan petugas kesulitan bekerja.

Faktor yang kedua adalah temperatur atau suhu di tempat kerja. Temperatur atau suhu di tempat kerja harus diperhatikan karena dalam keadaan normal, tiap anggota tubuh manusia mempunyai temperatur yang berbeda. Temperatur yang terlalu dingin akan mengakibatkan semangat kerja menurun, sedangkan jika terlalu panas, dapat mengakibatkan cepat merasa kelelahan dalam bekerja dan cenderung membuat banyak kesalahan.

Faktor yang selanjutnya adalah kelembaban di tempat kerja. Kelembaban adalah banyaknya air yang terkandung dalam udara, biasa dinyatakan dalam persentase. Kelembaban ini berhubungan atau dipengaruhi oleh temperatur udara, dan secara bersama-sama antara temperatur, kelembaban, kecepatan udara bergerak dan radiasi panas dari udara tersebut akan mempengaruhi keadaan tubuh manusia pada saat menerima atau melepaskan panas dari tubuhnya.

Faktor yang mempengaruhi selanjutnya adalah sirkulasi udara di tempat kerja. Sirkulasi udara di tempat kerja harus diperhatikan karena jika udara yang dihirup oleh petugas Rekam Medis didalam ruangan itu tidak higienis bisa mengakibatkan kesehatan menurun seperti sesak nafas. Kondisi lain yang dapat mempengaruhi adalah kebisingan di tempat kerja. Kebisingan di tempat kerja sebaiknya dihindari agar pelaksanaan pekerjaan dapat dilakukan dengan efisien sehingga produktiitas kerja meningkat.

Getaran mekanisme di tempat kerja juga dapat mempengaruhi, seperti kita ketahui getaran mekanisme adalah getaran yang ditimbulkan oleh alat mekanis, yang sebagian dari getaran ini sampai ke tubuh pegawai dan dapat menimbulkan akibat yang tidak diinginkan.Getaran mekanisme dapat menganggu tubuh manusia seperti konsentrasi bekerja berkurang, mudah lelah, kesesahan tubuh menurun.

Dekorasi di tempat kerja juga dapat mempengaruhi karena dengan menghias ruang kerja, mengatur tata letak dan perlengkapan dan lainnya untuk bekerja maka dapat membuat petugas merasa nyaman. Keamanan ditempat kerja juga sangat berpengaruh, hal ini guna menjaga tempat dan kondisi lingkungan kerja tetap dalam keadaan aman maka perlu diperhatikan adanya keamanan dalam bekerja. Faktor keamanan perlu diwujudkan. Salah satu upaya untuk menjaga keamanannya adalah dengan memanfaatkan tenaga satuan petugas keamanan.

Dari penjelasan diatas maka diharapkan kepada pihak rumah sakit Griya Husada Madiun untuk memperhatikan kondisi ruangan yang didalamnya perlu diperhatikan beberapa aspek yang meliputi pencahayaan, temperatur dan suhu, kelembaban, sirkulasi udara, kebisingan, dan dekorasi ruang terutama luas ruangan yang cukup untuk para petugas rekam medis 
agar dapat bergerak dan beraktifitas dengan baik dan nyaman dalam melaksanakan pekerjaannya dan meningkatkan kualitas kerja.

Apabila dibandingkan dengan teori belum memenuhi standar, pencahayaan sangat mempengaruhi manusia untuk melihat obyekobyek secara jelas, cepat tanpa menimbulkan kesalahan karena pencahayaan yang kurang mengakibatkan mata pekerja menjadi cepat lelah karena mata akan berusaha melihat dengan cara membuka lebar-lebar. Untuk mengatasi hal tersebut diharapkan kepada pihak rumah sakit untuk dapat menambahkan lampu pada masing-masing ruangan agar memenuhi pencahayan yang dianjurkan yaitu 300 Lux untuk ruang penyimpanan dan 350 Lux untuk ruang kerja (ruang pengolahan data).

\section{KESIMPULAN}

Kepuasan petugas rekam medis terhadap ruang rekam medis di Rumah Sakit Griya Husada Madiun belum sepenuhnya tercapai dan perlu dilakukan evaluasi.Kondisi ruang rekam medis di Rumah Sakit Griya Husada Madiun dengan ruang gerak yang sangat minimal dan menjadi satu dengan filling dokumen rekam medis pasien gawat darurat dapat menghambat pekerjaan petugas. Pencahayaan dan luas ruang rekam medis di Rumah Sakit Griya Husada Madiun adalah dengan pencahayaan
142,2 lux dan luas ruang $6 \mathrm{mx} 2 \mathrm{~m}$ dengan pembagian didalamnya terdapat 3 meja kerja dengan ukuran $120 \times 58 \mathrm{~cm} \times 77 \mathrm{~cm}$ dan 4 rak yang masing-masing berukuran $2 \mathrm{~m} \times 2.4 \mathrm{~m}$ dan $1.65 \mathrm{mx} 1.75 \mathrm{~m}$ hal itu menyebabkan sesak penuh dan akan menghambat pekerjaan dan produktivitas petugas.

\section{DAFTAR PUSTAKA}

Departemen Kesehatan RI. 2006, Pedoman Penyelenggaraan Dan Prosedur Rekam Medis Rumah Sakit di Indonesia. Jakarta: Depkes RI.

Herlambang, S. 2018, Customer Service Rumah Sakit dan Jasa Kesehatan, Yogyakarta: Gosyen Publishing.

Menkes RI. 2008. Peraturan Menteri Kesehatan RI Nomor 269/MENKES/PER/III/2008 Tentang Rekam Medis.

Nurminanto, Eko. 2008, Ergonomi: Konsep Dasar Dan Aplikasinya , Edisi kedua. Surabaya: Guna Widya.

Nurminanto, Eko.2004, Ergonomi: Konsep Dasar Dan Aplikasinya , Edisi Pertama. Surabaya: Guna Widya.

Sedarmayanti, 2013, Manajemen Sumber Daya Manusia, Bandung: Refika Aditama

Undang-Undang Nomor 44 Tahun 2009, Tentang Rumah Sakit. Jakarta: Sekretariat Kabinet Republik Indonesia. 2009 